\title{
POLÍTICA DE ESTADO OU DE GOVERNO? A REORIENTAÇÃO DA POLÍTICA EXTERNA BRASILEIRA SOB O GOVERNO BOLSONARO
}

\section{State or government policy? The reorientations of brazilian's foreign policy under the Bolsonaro administration}

João Victor da M. Baptista PPG em Relações Internacionais San Tiago Dantas (UNESP/UNICAMP/PUC-SP).

Artur Cruz Bertolucci PPG em Relações Internacionais San Tiago Dantas (UNESP/UNICAMP/PUC-SP).

Ana Victória Klovrza Diogo PPG em Relações Internacionais da Universidade Federal de Uberlândia (PPGRI - UFU).

\section{Informações do artigo}

Recebido em 21/06/2020

Aceito em 26/08/2020

doi>: https://doi.org/10.25247/2447-861X.2020.n250.p502-533

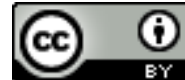

Esta obra está licenciada com uma Licença Creative Commons Atribuição 4.0 Internacional.

\section{Como ser citado (modelo ABNT)}

BAPTISTA, João V. M.; BERTOLUCCl, Artur Cruz.; DIOGO, Ana Victória K. Política de Estado ou de Governo? A reorientação da política externa brasileira sob o governo Bolsonaro. Cadernos do CEAS: Revista Crítica de Humanidades. Salvador/Recife, v. 45, n. 250, p. 502-533, maio/ago. 2020. DOI: https://doi.org/10.25247/2447-861X.2020.n250.p502-533

\begin{abstract}
Resumo
Os diferentes governos na história da República brasileira realizaram mudanças na condução da política externa, em maior ou menor grau, compartilhando, todavia, certos objetivos e valores. Essa aparente continuidade era justificada por um suposto insulamento burocrático do Itamaraty. Entretanto, a política externa atual apresenta um sério questionamento a essa ideia, uma vez que marca sua mais significativa ruptura, a partir da eleição de Jair Bolsonaro e a chancelaria de Ernesto Araújo. Este artigo, em diálogo com o histórico de produções acerca da Política Externa Brasileira, pretende demonstrar como esta não é uma política de Estado, mas sim uma política de governo, questionando o pressuposto amplamente difundindo do insulamento burocrático do Itamaraty. Compreende-se que a política externa está sujeita a barganhas políticas inerentes ao funcionamento do Estado, assim como as demais políticas públicas, apesar do notável déficit democrático nas disputas de poder e influência sobre sua condução política. A partir da revisão bibliográfica sobre o papel do Itamaraty e a Política Externa Brasileira, o artigo debate a evolução da temática na agenda eleitoral nacional e analisa a política externa dos três primeiros semestres do governo Bolsonaro.
\end{abstract}

Palavras-Chave: Política Externa Brasileira. Política pública. Insulamento. Déficit democrático. Jair Bolsonaro.

\section{Abstract}

The different governments in the Brazilian Republic story made changes in the conduct of foreign policy, to a greater or lesser degree, sharing, however, certain goals and values. This apparent continuity was justified by an alleged bureaucratic isolation from the Foreign Ministry. However, current foreign policy poses a serious challenge to this idea, since it marks its most significant rupture, after the election of Jair Bolsonaro and the chancellery of Ernesto Araújo. This article, in dialogue with the history of productions about the Brazilian Foreign Policy, intends to demonstrate how this is not a State policy, but a government policy, questioning the widely disseminated assumption of the bureaucratic isolation of the Foreign Ministry. It is understood that foreign policy is subject to political bargains inherent to the functioning of the State, as well as other public policies, despite the notable democratic deficit in the power and influence disputes over its political conduct. Based on the bibliographic review on the role of the Foreign Ministry and the Brazilian Foreign Policy, the article discusses the evolution of the theme in the national electoral agenda and analyzes the foreign policy of the first three semesters of the Bolsonaro government.

Keywords: Brazilian foreign policy. Public policy. Insulation. Democratic deficit. Jair Bolsonaro. 


\section{Introdução}

Historicamente, a política externa do Brasil é compreendida pela sociedade civil como uma área diferente das demais políticas públicas. Desde a Constituição de 1988, o processo de formulação e execução da política externa brasileira foi instituído como uma exclusividade do Poder Executivo federal, relegando aos outros poderes funções secundárias e a sociedade civil foi praticamente alijada de possibilidades de participação no processo decisório. Com exceção dos processos de ratificação e internalização no ordenamento jurídico brasileiro, as matérias de política externa no Congresso Nacional historicamente pouco impactaram ou influenciaram o processo decisório da política externa brasileira.

Ao longo do século $X X$, após a célebre chancelaria Rio Branco e as reformas institucionais do Ministério das Relações Exteriores (MRE ou Itamaraty), essa percepção de distanciamento do Itamaraty com a sociedade foi sendo ampliada. Foi propagado um discurso de máximo insulamento burocrático da pasta de relações exteriores, em que o Itamaraty monopolizaria a formulação e implementação da política externa - com um tom positivo por supostamente distanciar a política externa das mazelas da política interna (CHEIBUB, 1985).

As dinâmicas e complexidades do plano doméstico no estudo de Relações Internacionais por décadas estiveram ausentes do debate central da disciplina. $O$ avanço nas reflexões teóricas incorporou esse importante elemento às análises, com o objetivo de compreender a formação de preferências em Política Externa e os demais posicionamentos da política internacional dos Estados. A Análise de Política Externa (APE) possui uma forte contribuição no reconhecimento do papel dos atores domésticos na formulação de política externa com a intenção de construir uma abordagem teórica que abarcasse os diferentes níveis de análise (SNYDER et al., 1962; ROSENAU, 1967).

Instituições representativas e práticas representativas são o eixo central da difusão das preferências de grupos sociais e de indivíduos para as políticas de Estado (MORAVCSIK, 1997). As preferências de determinados grupos e indivíduos atuam na construção de políticas de governo por meio da pressão aos tomadores de decisão. A participação dos indivíduos é essencial, pois a imposição de decisões e a ausência de participação popular são elementos geradores de déficit democrático e da desvalorização das decisões (PECEQUILO, 2016). 
Compreender o valor democrático da legitimação da participação social na política externa nos conduz a reflexões acerca de sua finalidade dentro do Estado. Ou seja, sua concepção como política pública, assim como as demais áreas estatais, possibilitaria maior abrangência aos campos de diálogo e a institucionalização de espaços de debate entre sociedade e governos. Nesse sentido, possibilitaria uma série de reflexões sobre o processo decisório e as formas de legitimação das decisões políticas.

Assim, as questões que se colocam são as seguintes: A política externa brasileira é realmente uma política de Estado, ou seja, conseguiu realizar o insulamento burocrático? Ou seria a política externa, assim como as demais políticas públicas, sujeita às barganhas políticas internas ao funcionamento do Estado? Ademais, de que maneira a atuação internacional da gestão de Jair Bolsonaro corrobora para a análise de mudanças e continuidades na política externa brasileira?

\section{A história da política externa brasileira e o papel do Itamaraty}

Na primeira metade do século $X X$, ocorreram reformas administrativas no Estado brasileiro inspiradas no modelo weberiano de racionalização das instâncias governamentais. Desde então, o insulamento burocrático é almejado como a mais eficiente forma de se governar. Nessa visão, a abordagem técnica deve ser priorizada, em detrimento da abordagem política, a fim de que disputas de poder não interfiram no processo decisório e a solução mais eficiente seja formulada e implementada.

É comumente admitido pela literatura que esse processo de racionalização teria ocorrido, ao longo do último século, com as decisões sobre política externa (CHEIBUB, 1985). De forma praticamente evolutiva, o Ministério das Relações Exteriores do Brasil (MRE ou Itamaraty), teria passado de uma fase patrimonialista pouco competente para um elevado grau de insulamento das disputas políticas, para tornar-se altamente técnico e eficiente.

O serviço exterior, principalmente durante o período imperial (1822-1889), teve o patrimonialismo como lógica de funcionamento. Consistia em uma administração com baixo comprometimento com os interesses nacionais e de promoção do bem-estar do povo brasileiro. A seleção do corpo diplomático era feita livremente pelos governantes, muitas vezes escolhendo familiares ou aliados para os cargos que exigiam conhecimento técnico. Os interesses particulares dos administradores e governantes eram priorizados em detrimento 
dos interesses públicos em geral. O filhotismo (ou seja, o favorecimento de aliados ou parentes sem considerar o critério de competência) e o baixo grau de racionalização da administração pública atingia também, portanto, o Ministério das Relações Exteriores (CHEIBUB, 1985).

Um exemplo desse patrimonialismo foi a troca na chefia das negociações de reconhecimento da independência do Brasil pela Inglaterra e por Portugal, respectivamente, o país mais poderoso e influente do século XIX e o antigo colonizador D. Pedro I, imperador do Brasil, preferiu retirar José Bonifácio de Andrada do comando das negociações e o próprio imperador as assumiu. Bonifácio negociava com o objetivo de priorizar os interesses econômicos e políticos do Brasil. Já o imperador almejava produzir um acordo que priorizasse os interesses da dinastia de Orleans e Bragança, a fim de preservar a posição privilegiada da Casa de Bragança tanto na Europa como na América. Para isso, necessitava do apoio inglês na negociação com Portugal, de modo que concedeu inúmeras vantagens comerciais e políticas à Inglaterra em troca desse apoio (RICUPERO, 2011).

Devido a experiências de ineficiência como essa, o isolamento das pastas técnicas das questões políticas está frequentemente associado com maior eficiência, objetividade e continuidade nas políticas públicas. No caso da política externa no Brasil, entendeu-se que esse processo evolutivo do patrimonialismo, ao modo de organização racional-burocrático, teria de fato ocorrido e, por isso, é constantemente exaltado como o caso de sucesso dentre as pastas ministeriais (CHEIBUB, 1985).

Devido à sua composição exclusiva de pessoal concursado desde a reforma administrativa na primeira metade do século $X X$, sua pouca transparência em termos de negociação e implementação de suas funções e sua rasa mobilização em termos eleitoreiros, convencionou-se a ideia de que o Itamaraty funcionava de maneira independente das dinâmicas políticas internas. A política externa pareceu, assim, ser artificialmente segregada das demais políticas públicas.

O discurso de que o Itamaraty haveria atingido o ápice do insulamento burocrático foi amplamente difundido na literatura e no imaginário social (CASARÕES, 2012). Por esse motivo, o Ministério das Relações Exteriores foi historicamente elogiado por supostamente monopolizar não só a implementação, mas também a formulação da política externa. Com isso, logrou-se um suposto isolamento da política externa das demais políticas públicas, as quais estariam demasiadamente poluídas pela interferência política em detrimento da 
técnica. Grande parte da literatura admite que foi devido a esse insulamento burocrático que se puderam consolidar os grandes pilares da política externa brasileira (PEB) ao longo dos anos: o americanismo, o universalismo, o objetivo de desenvolvimento econômico, a preferência pela solução pacífica de controvérsias, a não intervenção em assuntos estrangeiros, entre outros (FARIA, 2012; PINHEIRO; MILANI, 2013).

Foi ainda na chancelaria chefiada pelo Barão do Rio Branco (1902-1912) que teve início o paradigma americanista na PEB. Enquanto a diplomacia do Império priorizava a Europa como região de interesse prioritário, Rio Branco realizou uma análise correta nos anos 1900, antevendo a preponderância dos Estados Unidos no sistema internacional ao longo do século XX, ultrapassando a hegemonia europeia há séculos consolidada. Por isso, decide aproximar o Brasil do país norte-americano, a fim de obter vantagens políticas e econômicas dessa aproximação. A aproximação, baseada em cálculos de custos e benefícios, não meramente ideológica, ficou conhecida como americanismo pragmático (CERVO; BUENO, 2002).

Além disso, a gestão Rio Branco foi responsável por dar ênfase a outras duas características que qualificaram a PEB durante o século XX e início do XXI. A primeira é o interesse pelas relações com o entorno regional, materializada na tentativa de realizar um acordo regional entre Argentina, Brasil e Chile (ou Pacto $A B C$ ), o que significava uma aproximação política e comercial com a América do Sul. O pacto, entretanto, não foi ratificado pelos Estados. A segunda é a preferência pelo multilateralismo, ou seja, a predileção de negociar em âmbitos multilaterais (como em Organizações Internacionais) ao invés de negociar bilateralmente (RICUPERO, 2017).

A partir do primeiro governo Vargas (1930-1945), inaugurou-se o objetivo primordial da política externa brasileira que orientou as decisões internacionais do Estado brasileiro ao longo de quase todo o século XX: o desenvolvimentismo. O principal objetivo de governo de Vargas consistia em industrializar o Brasil. Para isso, utilizou da política externa como instrumento para o desenvolvimento econômico do país, proporcionando parcerias estratégicas, transferência de tecnologia e investimentos externos (CERVO; BUENO, 2002).

Sabendo que o Brasil seria um aliado importante na escalada de tensões que culminou na Segunda Guerra Mundial, Vargas atingiu seu objetivo de realizar a industrialização de base ao barganhar entre os EUA e a Alemanha hitlerista para conseguir os recursos necessários. 
Com a entrada dos EUA na guerra, no fim de 1941, o Brasil se volta ao americanismo pragmático e declara guerra à Alemanha (MOURA, 1984).

Com o início da Guerra Fria (1947), o governo Dutra (1946-1951) inaugurou o que ficou conhecido como paradigma do americanismo ideológico. Na Guerra Fria, a aproximação brasileira com os EUA se realizou não necessariamente por trazer vantagens materiais ou políticas, mas sim por uma questão ideológica moldada pela política mundial bipolar: não se aproximar dos EUA significava dar margem ao comunismo (CERVO; BUENO, 2002).

Entretanto, mesmo com apoio aos posicionamentos estadunidenses, as contrapartidas econômicas e políticas não ocorreram na mesma proporção. O Brasil apoiou as iniciativas estadunidenses de criação do Tratado Interamericano de Assistência Recíproca (TIAR) e a Organização dos Estados Americanos (OEA), seguiu o posicionamento dos EUA ao reconhecer Taiwan (capitalista) como a legítima China após a Revolução de 1949 e rompeu relações diplomáticas com a União Soviética. Já que a América Latina era entendida como um local de influência estadunidense inconteste, o radar de política externa dos EUA estava voltado para a contenção do comunismo na Europa e na Ásia. Assim, os investimentos para desenvolvimento e reconstrução no pós-guerra foram direcionados para essas regiões (como o Plano Marshall e o Plano Colombo) e não para a América Latina (CERVO; BUENO, 2002; RICUPERO, 2017).

Durante o governo Juscelino Kubitschek, houve um redirecionamento da política externa sinalizando o abandono do americanismo ideológico. JK também não conseguiu os investimentos estadunidenses desejados para avançar no processo de desenvolvimento do Brasil - simbolizado pelo fracasso da Operação Pan-Americana, um projeto regional que envolvia a promoção de desenvolvimento econômico para a América Latina com investimentos estadunidenses. A diplomacia brasileira, então, se volta para a expansão de parcerias e inicia um novo paradigma na política externa, o universalismo (CERVO; BUENO, 2002). O universalismo consiste no entendimento de que os objetivos de política externa podem ser alcançados de forma mais eficiente com múltiplas parcerias, e não com a priorização de uma relação em detrimento de outras.

O universalismo foi aprofundado pelos governos de Jânio Quadros e João Goulart (1961-1964). A política externa brasileira passou por um período de grande expansão de parcerias, de cooperação com o Terceiro Mundo, de pragmatismo e autonomia na gestão dos interesses do Brasil sem restrições ideológicas. Em meio à Guerra Fria, o Brasil continuou se 
posicionando como pertencente ao bloco capitalista, todavia, sua atuação internacional seria independente de decisões de outros países, visando principalmente ao desenvolvimento nacional. O Brasil passou a defender a descolonização, condenou a invasão à Baía dos Porcos (Cuba), ampliou relações comerciais com o bloco socialista, reatou relações diplomáticas com a União Soviética, sem deixar de posicionar-se como capitalista na esfera econômica (AMADO, 1996; CERVO; BUENO, 2002).

Com o golpe-civil militar de 1964, houve grande ruptura na cadência seguida pela política externa nos anos anteriores. Atualmente, já foi provada a interferência dos EUA na política nacional em favor do golpe (FICO, 2008), o que facilita o entendimento do retorno da política externa para o americanismo ideológico. Um exemplo desta ruptura é o episódio do envio de tropas pelo Brasil à intervenção na República Dominicana chefiada pelos EUA nos anos 1960, rompendo com a tradição da não intervenção e da solução pacífica de controvérsias. Ademais, o Brasil passa a adotar políticas econômicas liberais - convergentes com o Fundo Monetário Internacional (FMI) e Washington, além de pagar a indenização exigida pelos EUA pelas empresas estadunidenses nacionalizadas no governo João Goulart (CERVO; BUENO, 2002).

Já nos demais governos da ditadura militar, de Costa e Silva a Figueiredo (1967-1985), houve um retorno ao universalismo e a retomada da autonomia. Assim como no período após o governo Dutra (1946-1951), percebeu-se que os retornos da política externa de Castelo Branco não foram significativos em termos de vantagens econômicas. Devido ao retorno da priorização dos objetivos de desenvolvimento e também devido às crises econômicas mundiais dos anos 1970 e 1980, foi feito o cálculo de que a alternativa mais vantajosa ao Estado brasileiro seria a diversificação de parcerias para atrair investimentos externos de diversos países e cativar outros mercados consumidores (CERVO; BUENO, 2002).

Em linhas gerais, a história da política externa brasileira (PEB) evidencia que o Brasil tem alguns objetivos de política externa presentes na maior parte do tempo. Entre esses estão a promoção do desenvolvimento econômico, a defesa da autonomia frente ao alinhamento, a manutenção de boas relações tanto com países desenvolvidos como em desenvolvimento, a ampliação dos mercados externos para as mercadorias brasileiras, a busca pelo prestígio na política internacional, a não intervenção em assuntos domésticos de outros países, a defesa do multilateralismo e a busca pelo protagonismo regional. Assim, 
percebe-se que a PEB tem como tensões o americanismo versus o universalismo, ou 0 alinhamento versus a autonomia.

A história também nos ensina que os posicionamentos da política externa brasileira não se mantêm (ou se alteram) devido a um suposto insulamento burocrático do Itamaraty. O Ministério das Relações Exteriores não tem o condão de definir os direcionamentos das ações internacionais do Estado brasileiro por si só (PINHEIRO; MILANI, 2013). A história nos mostra que as continuidades e mudanças na política externa - como a escolha pelo americanismo ou pelo universalismo, posturas autonomistas ou alinhadas - ocorrem por diversos fatores, por exemplo, mudanças de governo, de grupos que influenciam o poder e do cenário internacional.

O contexto do último quartel do século XX, em especial, não era favorável a tentativas de insulamento burocrático. Houve o fim da ditadura civil-militar no Brasil, simultaneamente ao fim da Guerra Fria, ao início da Revolução técnico-científica-informacional, o aprofundamento do processo de globalização e a atuação internacional de cada vez mais atores (organizações não governamentais, entes governamentais subnacionais, empresas, movimentos sociais, indivíduos, etc.). Todos esses eventos foram fatores que pressionaram o Itamaraty por mais transparência - ainda escassa - e porosidade na formulação de política externa (FARIA, 2012; PINHEIRO; MILANI, 2013).

À luz da metodologia de Análise de Política Externa (APE) (PINHEIRO; MILANI, 2013), bem como do 'jogo de dois níveis' proposto por Robert Putnam (1988), pode-se afirmar que a política externa, assim como as demais políticas públicas, não são isentas de processos de barganha política, negociação com grupos de interesse e influências ideológicas e partidárias. A premissa da existência de um interesse nacional único, formulado apenas pelo Estado, cujo objetivo principal seria garantir a sobrevivência e segurança do país não se sustenta, segundo a metodologia da APE.

Segundo a APE, a política externa não pode ser analisada apenas "de fora para dentro", mas sim, e principalmente, "de dentro para fora". Isso quer dizer que o estudo de política externa deve levar em conta os acontecimentos internacionais que influenciam o Estado a ter um determinado posicionamento; mas também deve analisar as pressões de grupos internos sobre o Estado que levou os burocratas do Itamaraty a tomarem uma determinada decisão (PINHEIRO; MILANI, 2013). 
É nesse sentido que a categorização feita por Charles Hermann (1990) auxilia na compreensão das continuidades e mudanças na política externa, uma vez que leva em consideração fatores internos e externos ao Estado para avaliá-las. Em 'Mudando a rota: quando governos escolhem redirecionar a política externa' ${ }^{1}$, Hermann (1990) propõe um método de análise baseado em níveis graduais de mudança em política externa. A partir dessa metodologia, categorizam-se as continuidades e modificações dessa política pública, bem como quais agentes promovem essas mudanças.

Hermann (1990) propõe quatro níveis de mudança na política externa de um Estado. O primeiro consiste na mudança de ajuste. São mudanças superficiais, as quais não alteram os objetivos de política externa do Estado, bem como são mantidos seus métodos de implementação e programa. Desse modo, a mudança reside no esforço empreendido para atingir determinados objetivos, ainda que esses objetivos permaneçam. O segundo nível consiste na mudança de programa, no qual também permanecem os mesmos objetivos, entretanto, modificam-se os meios de ação para atingi-lo (HERMANN, 1990).

O terceiro nível consiste na mudança de metas e objetivos da política externa, a qual se verifica quando os objetivos iniciais de ação internacional do Estado são substituídos por outros, engendrando uma mudança em maior grau na condução da política externa. Por fim, o quarto nível consiste na mudança de orientação internacional, sendo a forma mais extrema de mudança, uma vez que redireciona a ação internacional do Estado de maneira que haja expressiva ruptura com as diretrizes anteriormente praticadas (HERMANN, 1990).

Há agentes que engendram essas mudanças na política externa ao influenciarem no processo de tomada de decisão. Esses agentes podem ser líderes governamentais; burocratas, quando um grupo de tomadores de decisão começar a advogar e fomentar mudanças na condução da política externa; uma reestruturação doméstica, quando há reestruturação política e institucional no aparelho estatal; e, por último, os choques externos, quando uma mudança na política externa ocorre devido a eventos internacionais que impactam uma agenda nacional e, sobretudo, em como os formuladores de política externa do país os interpretam e reagem a eles (HERMANN, 1990).

\footnotetext{
${ }^{1}$ No original: Changing course: When governments choose to redirect foreign policy.
} 


\section{Política externa na Agenda eleitoral da Nova República}

Como demonstrado na seção anterior, na história brasileira o interesse pela política externa para o conjunto da sociedade nunca foi estimulado pelo Estado e por suas burocracias - como o Itamaraty, que, por décadas, se valeu do pretenso insulamento burocrático sobre o qual discorremos. No entanto, no período recente e em especial após a redemocratização, os debates em torno da política internacional do país foram, pouco a pouco, incorporados pelos políticos e nos embates ideológicos.

Ademais, percebemos que mudanças são possíveis e mais frequentes do que alguns gostariam. Tal situação decorre do fato de a política externa ser uma política pública e, portanto, de governo, estando sujeita às preferências das elites e grupos de interesse no poder em determinado momento. No Brasil, essa posição não é diferente, estando a política externa sujeita às prioridades ideológicas do bloco no poder.

Pode-se chegar a tal conclusão de diferentes maneiras, uma delas foi feita na seção anterior, na medida em que apresentamos as continuidades, mudanças e escolhas feitas ao longo dos anos na ação internacional brasileira. Porém, para além da aplicação efetiva da PEB, outra maneira de constatarmos que esta é uma política pública é a partir de como essa aparece na sociedade. Um bom momento para avaliar a importância da PEB é o período eleitoral, em que a sociedade está mais propensa a debater política e as ideologias que disputam o pleito.

Entre 1964 e 1989, entretanto, o Brasil não presenciou eleições para o executivo, inviabilizando qualquer tipo de debate público e social da política externa. Contudo, com o final da ditadura civil-militar, o Brasil vivenciou, em conjunto com as mudanças nas instituições e legislações, uma alteração no padrão de atuação dos atores sociais, com maior demanda por participação e construção de canais de diálogo (FARIA, 2010). Dessa forma, as discussões acerca da participação social na política externa brasileira são retomadas após a redemocratização e a instituição dos conselhos ${ }^{2}$ com a Constituição Federal de 1988.

No primeiro processo eleitoral após o fim da ditadura civil-militar, imerso no ambiente de crise do regime soviético e as vésperas do fim da Guerra Fria, o debate político foi

\footnotetext{
2 Nesse período foram instituídos conselhos e conferências nas áreas de educação, saúde, trabalho, previdência social, assistência social, segurança alimentar, cidades e desenvolvimento rural.
} 
contagiado pela retórica modernizante e alinhada às perspectivas dos países centrais do capitalismo. Essa perspectiva se acentuou no segundo turno com a polarização entre o eleito, Fernando Collor, e seu oponente, Lula da Silva, que defendia um programa fortemente marcado por uma posição contrária ao status quo. No geral, os temas de política internacional que se destacaram foram a problemática da dívida externa brasileira e temas relacionados à Amazônia (LOPES; FARIA, 2014).

Os anos 1990 inauguram uma longa bipolarização na política brasileira entre o Partido da Social Democracia Brasileira (PSDB) e o Partido dos Trabalhadores (PT). Os dois pleitos para o executivo federal dessa década (1994 e 1998) culminaram na eleição de Fernando Henrique Cardoso frente a Lula da Silva. A política econômica esteve na centralidade desses debates, em virtude da estabilização monetária lograda pelo Plano Real. No entanto, os planos de governo do PT apresentavam algumas agendas políticas para o debate internacional, tais quais a integração regional, as alianças com países do Sul Global e a necessidade de repensar o papel do legislativo e da sociedade civil na PEB (PARTIDO DOS TRABALHADORES, 1994; 1998).

A década de 1990 foi marcada pela constituição de inúmeros blocos econômicos regionais, tais quais o Mercado Comum do Sul (Mercosul), o Tratado Norte-Americano de Livre Comércio (Nafta) e a reorientação da Comunidade Andina de Nações (CAN). O Mercosul teve como meta, além da criação de uma área de livre-comércio, a "[...] constituição de um mercado comum, com tarifa externa comum e atuação conjunta entre os membros em negociações externas" (MELLO, 2002, p. 38).

A constituição do Mercosul iniciou um longo processo por maior participação social na política externa do país, pois, desde o início das negociações do bloco, houve intenso envolvimento de atores sociais - em especial, as centrais sindicais e confederações patronais (MARIANO, 2011; BAPTISTA, 2020). Da mesma forma, esses atores sociais se engajaram ativamente nos processos de negociação da Área de Livre Comércio das Américas (ALCA).

As discussões acerca dos processos de liberalização econômica e da formação de blocos econômicos regionais e/ou hemisféricos cindiu dois projetos políticos e duas concepções acerca do regionalismo e do papel da política externa. Em certa medida, esses projetos orbitavam dentro dos paradigmas da política externa brasileira de autonomia e alinhamento com os Estados Unidos. Nas eleições de 2002, essas concepções foram 
trabalhadas pelas candidaturas do candidato oficialista José Serra e Lula da Silva, novamente o principal candidato da oposição.

Naquele processo eleitoral, Lula da Silva era tachado como um candidato de ruptura dos regimes internacionais, com a presunção de que ele "[...] romperia com o Fundo Monetário Internacional e daria calote na dívida externa brasileira" (LOPES; FARIA, 2014, p. 143). Cabe salientar que José Serra como discurso contrario a Lula da Silva apontava que sua vitória transformaria o país "em uma Venezuela" (ULHÔA, 2002). Com sua vitória, verificouse que tais presunções não se concretizaram, mas houve uma reorientação da PEB que o assessor especial da Presidência da República para Assuntos Internacionais Marco Aurélio Garcia definiu como uma opção sul-americana.

A opção sul-americana pode ser sintetizada para Garcia (A OPÇÃO..., 2017) com os seguintes fatos: a reorientação do Mercosul e a inclusão de novos membros, a criação de novas institucionalidades como a União de Nações Sul-Americanas (Unasul) e a Comunidade de Estados Latino-Americanos e Caribenhos (Celac), as tentativas de participar e dialogar com os Andes e, no conflito colombiano, além de construir iniciativas de diálogo para solução de diversas controvérsias no período.

No plano regional, a eleição de Lula da Silva foi acompanhada da denominada onda rosa na América Latina, com a eleição de governos de esquerda e centro-esquerda nos países do bloco, que proporcionou um giro na agenda política regional. Esse processo culminou na derrota do projeto da ALCA, na criação das novas institucionalidades (Unasul e Celac) e na transformação do Mercosul. O fenômeno de reorientação na concepção e propostas de regionalização se assentou em um modelo que tinha como principais características a primazia da agenda política, do papel do Estado na coordenação econômica e na implementação de políticas sociais, como a redução de assimetrias estruturais e a inclusão de segmentos antes excluídos da cidadania política (LIMA, 2013).

Nas eleições de 2006, a candidatura à reeleição de Lula da Silva realizou uma inédita inserção no programa eleitoral para debater a política externa e o tema adquiriu notoriedade nos debates eleitorais, em especial a atuação brasileira frente à questão do gás natural boliviano e a nacionalização da sede da Petrobrás no país (LOPES; FARIA, 2014). De certo modo, o momento político latino-americano, marcadamente favorável às forças progressistas e de esquerda, iniciou um processo de renascimento dos fantasmas políticos da Guerra Fria nos setores hegemônicos brasileiros. 
Em perspectiva da sociedade civil, os anos 2000 foram marcados por uma ampliação dos debates sobre a política externa e a integração regional, em especial pela inclusão de novas agendas aos debates, tais quais: política, institucional, energética, física, comercial, ambiental, científica, tecnológica, cultural e social. Nesse período, nota-se uma ação dos governos petistas para incluírem, por meio da Secretária Geral da Presidência da República, distintos atores sociais nos debates sobre política externa e com intuito de potencializar os espaços de participação social do Mercosul (BAPTISTA, 2020).

Nas eleições presidenciais de 2010, a candidatura oficialista de Dilma Rousseff (PT) foi questionada em diversos momentos pelo oposicionista José Serra (PSDB) acerca dos temas da política internacional dos governos petistas. Dentre os temas levantados, a candidatura tucana inquiriu sobre a proximidade brasileira com os governos do Irã, da Venezuela e de Cuba, bem como a permissividade do governo com a atuação de narcotraficantes nas regiões de fronteira (LOPES; FARIA, 2014).

O debate de projetos políticos distintos, que sempre foi presente nas disputas entre PT e PSDB, se transformou em uma disputa ideológica, com uma perceptível alteração no tom dos questionamentos frente aos governos pelos seus oposicionistas. A concepção dos partidos de direita e centro-direita no Brasil acerca das ações da política externa petista era que esta se tratava de um projeto político-ideológico associado a regimes não democráticos e que violavam os direitos humanos - em clara associação de governos de esquerda com tais práticas.

Nas eleições de 2014, a política externa foi presente em quase todos os planos de governos dos presidenciáveis, fato que mostrava a crescente importância do tema para a agenda política nacional, no entanto, foram relegadas a um papel secundário ao longo dos debates em virtude do acirramento da disputa (LOPES; FARIA, 2014). O principal candidato da oposição, Aécio Neves, apontava a necessidade de recuperar a centralidade da política externa para as ações comerciais, ressaltava a importância da burocracia do Itamaraty e outras questões que apontavam para o desejo de reorientar a PEB para maior alinhamento com a agenda estadunidense (AÉCIO..., 2014).

A questão da participação da sociedade civil na política internacional apareceu como ponto de debate nos programas de governo de Rousseff e Neves. O programa petista previa uma continuidade do trabalho executado nos governos anteriores, enquanto o programa 
tucano apresentava a necessidade de ampliar a participação empresarial na agenda comercial, demovendo a área da responsabilidade do Itamaraty (MILANI; PINHEIRO, 2017).

Nesse período, nota-se o enfraquecimento dos governos progressistas e de centroesquerda em toda a América Latina, impactados diretamente pelas consequências da crise econômica de 2008 e a redução do preço das commodities - que foram essenciais para potencializar o crescimento econômico e possibilitar a construção de políticas sociais que foram marcas desses governos. Em virtude disso, iniciou-se um processo de derrotas eleitorais, de golpes de Estado (Honduras e Paraguai) e de esgotamento dessas experiências.

Na perspectiva regional, houve um enfraquecimento das experiências regionais e a desaceleração no desenvolvimento institucional dos mecanismos de integração, tais quais a Unasul, a Celac e o próprio Mercosul. Nesse período, ressurgem debates para construção de iniciativas regionais exclusivamente econômicas e comerciais, que culminaram na criação da Aliança do Pacífico, observada com entusiasmo pelos oposicionistas dos governos progressistas em toda a região e utilizada como síntese de suas perspectivas acerca do regionalismo sul-americano.

O segundo mandato de Dilma Rousseff foi breve e conturbado. Nos primeiros meses após as eleições, inúmeros grupos que apoiaram a presidenta começaram um processo de mobilizações contra seu governo em virtude da composição ministerial - com críticas em especial a Joaquim Levy33. Além disso, a derrota na indicação do Presidente da Câmara dos Deputados para Eduardo Cunha gerou um revés na relação com os partidos do centro político.

O processo de forte desgaste social, a incapacidade do governo de apontar soluções para a crise econômica e o aumento do desemprego culminaram num processo de impeachment da presidenta, sob justificativa de "pedaladas fiscais" (BAPTISTA; BERTOLUCCI, 2020). A conclusão do processo de ruptura democrática no Brasil, efetiva o vice-presidente Michel Temer, do Movimento Democrático Brasileiro (MDB), na presidência da república, com uma agenda política oposta à dos governos petistas.

\footnotetext{
${ }^{3}$ Economista ortodoxo que construiu carreira na iniciativa privada e no mercado financeiro. Foi nomeado como Ministro da Fazenda do segundo mandato de Dilma Rousseff com o intuito de aplicar uma agenda econômica de ajustes fiscais.
} 
A política externa do governo Temer foi chefiada por dois quadros relevantes do PSDB, os então senadores José Serra e, posteriormente, Aloísio Nunes. De início, a política internacional voltou a ser orientada por princípios liberais, em discursos dos chanceleres sobre a importância de a diplomacia refletir os valores brasileiros e não ser conivente com as preferências e conveniências ideológicas de nenhum partido político (BAPTISTA; BERTOLUCCI, 2020).

A questão ideológica na política externa foi um eixo central das críticas do governo Temer, ao mesmo tempo em que, no âmbito regional, buscava um realinhamento com a Argentina (no momento, sob o governo de Maurício Macri) e promoveu a expulsão da Venezuela do Mercosul, sob argumentação de que o país não havia internalizado os acordos de adesão ao bloco. A questão Venezuela esteve na centralidade do debate político regional, cabe ressaltar que, apesar da argumentação tecnicista, a expulsão da Venezuela teve forte aspecto político, visto que alguns acordos do Mercosul, inclusive utilizados na expulsão, também não foram internalizados pelos membros fundadores (BAPTISTA, 2020).

As eleições de 2018 elevaram a política externa à centralidade de inúmeras discussões com inúmeros momentos de protagonismo nos debates televisivos como o caso da "URSAL"4, o fantasma da possibilidade de o "Brasil virar uma Venezuela"5, o papel do Foro de São Paulo, e outras temáticas relacionadas a debates pontuais sobre comércio e acordos regionais. Em relação aos planos de governo, os principais candidatos à presidência apontaram suas predileções e pretensões para a pauta, como mostra o relatório do Observatório do Regionalismo (2018), os dois principais candidatos, Jair Bolsonaro e Fernando Haddad (PT), apresentaram visões diametralmente opostas sobre a política externa e a integração regional.

A América Latina apareceu nesse processo eleitoral como um território em disputa, em especial em torno da dicotomia a defesa parcial ou total da política externa dos governos

\footnotetext{
${ }^{4}$ No debate presidencial de primeiro turno na Bandeirantes, o candidato Cabo Daciolo do Partido Patriotas questionou Ciro Gomes (PDT) sobre o que ele pensava sobre o "Plano Ursal" que seria a sigla para "União das Repúblicas Socialistas da América Latina", fato que resultou em um momento de alívio cômico entre os candidatos. Esse pretenso plano consistiria na ideia de organizações como o Foro de São Paulo pretenderem constituir uma república unitária de recorte socialista na região, em clara alusão às iniciativas de integração regional desenvolvidas pelos governos progressistas na região.

${ }^{5}$ Argumento utilizado por eleitores de direita no Brasil durante o período eleitoral de 2018, em referência à crise econômica, política e democrática que a Venezuela vivenciava como tentativa de desmoralização da política externa petista e a gestão do partido.
} 
Lula da Silva e Dilma Rousseff e a busca por caracterizar as relações dos governos petistas como não desejáveis ou com a necessidade de repudiar regimes ditatoriais. Nesse sentido, o debate ideológico foi colocado no centro da conversa sobre política externa e, com a eleição de Jair Bolsonaro, o tom dos discursos elevou-se para outro patamar, rompendo quaisquer barreiras que pretensamente insulavam o Itamaraty.

O histórico apresentado aponta para a forte presença da discussão sobre ideologia na política internacional brasileira, além do crescimento da pauta no cenário político nacional, apesar da concepção de que 'política externa não ganha eleição'. Este fato ressalta a importância de refletirmos sobre a formulação dessa política e a necessidade da sua concepção como uma política pública, como as demais áreas, cabendo a necessidade do debate público, a participação e a prestação de contas.

A condução da política externa carece de transparência e regularmente promove a omissão de informações sobre negociações bilaterais ou multilaterais ao conjunto da população. Pensar formas de participação social nos espaços do Itamaraty e formas de accountability acrescentaria garantias democráticas essenciais para o controle social das decisões governamentais.

Da mesma forma, uma participação mais ativa do Poder Legislativo nos possibilitaria vantagens tais quais a descentralização decisória e maior democratização dos acordos comerciais (OLIVEIRA, 2003). Além disso, no parlamento, os partidos políticos poderiam exercer seus papéis de discussão e formulação possibilitando um maior refinamento nos consensos políticos externos.

No último período, as discussões, nas ciências sociais aplicadas, sobre Governo Aberto passaram a discutir um instrumental prático e aliado à tecnologia de possibilitar ao conjunto dos cidadãos desempenharem um papel mais ativo na gestão pública desde a fiscalização e controle até um instrumental de compartilhamento decisório. Dentre alguns princípios de governo aberto temos: participação efetiva; transparência e responsabilidade; dados abertos; acesso e simplicidade; entre outros (BELLIX; GUIMARAES; MACHADO, 2016).

A concepção de governo aberto é compreendida por diferentes níveis de transparência e de participação social, mas, em síntese, corresponde a uma forma de interação sócio política para ampliar a transparência, a participação social e democratizar processos (CRUZ-RUBIO, 2015). As ferramentas de governo aberto, aliadas às tradicionais práticas de constituição de conselhos e conferências, possibilitariam uma reflexão sobre o 
processo decisório em política externa e a constituição de um novo instrumental para além da centralização burocrática.

\section{A política externa no governo Bolsonaro}

As rupturas Governo Bolsonaro se iniciaram no momento da nomeação dos principais ministros para compor seu governo. No Ministério das Relações Exteriores, Ernesto Araújo foi escolhido para conduzir o novo período da pasta; oriundo das fileiras do Itamaraty, o diplomata se destacou logo em seu discurso de posse (ARAÚJO, 2019) ao afirmar que orientaria o ministério contra os valores do 'globalismo' ${ }^{6}$, a necessidade de se libertar do Foro de São Paulo, fez críticas à atuação das ONGs, fez menções à luta contra o direito ao aborto, exaltou Deus e a família, além de apontar sua admiração à Israel.

Nos primeiros meses de governo, Brasília delineou seu alinhamento políticoeconômico aos EUA, o distanciamento da região e do Sul Global (BAPTISTA; BERTOLUCCI, 2020). Esses posicionamentos se evidenciaram nas constantes críticas aos seus antecessores pelo distanciamento dos Estados Unidos e a aproximação com parceiros na Europa e com os BRICS. Ademais, diversas alterações no corpo diplomático foram realizadas com o intuito de nomear diplomatas alinhados com as propostas do governo, com demissões, inclusive, de quadros críticos aos governos petistas, mas não alinhados ao perfil ultraconservador de Ernesto Araújo.

Um dos primeiros espaços em que o governo Bolsonaro já apresenta suas cartas é na preferência pelo bilateralismo, em contraposição ao multilateralismo que marcava a PEB no período anterior (CHADE, 2019). Ademais, essa reorientação também foi feita em relação aos parceiros que o Brasil daria prioridade no cenário internacional. Ernesto Araújo e Bolsonaro deixaram claro que o país procuraria se aproximar do centro do capitalismo e de países ideologicamente alinhados. Exemplo disso é a aproximação do Brasil de Israel, validando, no discurso, o histórico pleito desse país sobre a capital disputada com a Palestina: Jerusalém (VALLADÃO, 2018; MEDEIROS, 2019; BOLSONARO..., 2020)

6 Conceito utilizado pelo ministro, em referência a formuladores políticos de extrema direita, que tenta apontar que a ordem global vigente é orientada contra as liberdades individuais, uma suposta dominação de esquerda nos fóruns multilaterais que busca reduzir a autonomia e soberania dos Estados. 
A dimensão regional foi desestruturada por Bolsonaro, em abril de 2019 o país formalizou sua saída da Unasul (VERDÉLIO, 2019) após o governo antecessor ter suspendido a participação do país, junto a outros países sob regimes de direita e centro-direita. Esse fato iniciou uma série de ações do governo de inclusão de sua agenda ideológica nas relações bilaterais e multilaterais conforme antecipado pelas declarações de Jair Bolsonaro, seus filhos e seu alto escalão governamental.

A agenda ideológica nacional e os setores prioritários da base eleitoral bolsonarista receberam do governo diversas sinalizações; em ações inéditas, o Brasil mudou o conteúdo de sua participação em diversos fóruns multilaterais para defender os interesses dos segmentos conservadores e de frações religiosas. Na ONU, o país passou a votar de forma contrária ao direito de acesso universal a serviços de saúde reprodutiva e sexual para mulheres (QUERO, 2019), pois o governo Bolsonaro considerou que esse trecho possibilitava margem de interpretação sobre a possibilidade de as mulheres terem direito ao aborto legal e seguro - um posicionamento também adotado na política interna em concordância com a base de apoio religiosa. Em outra oportunidade, a Ministra Damares Alves voltou a manifestar o posicionamento do governo aos valores religiosos contrários ao aborto (CERIONI, 2019).

Outro elemento de forte recorte ideológico na política externa de Bolsonaro é a agenda climática, com negacionismo científico e forte entusiasmo pela destruição ambiental (MINISTRO..., 2020). Tais posicionamentos externos, além da promoção institucional do desmatamento na Amazônia têm deslocado o país de seu protagonismo histórico nos fóruns climáticos. A 25 Cúpula do Clima que inicialmente aconteceria no país, mas foi rejeitada pelo governo, ocorreu sem a presença do presidente da república (BOLSONARO..., 2019a). Ademais, a Cúpula foi ironizada pelo Ministro do Meio Ambiente, Ricardo Salles do Partido Novo, que, durante sua gestão, coleciona polêmicas por sua negligência no combate ao desmatamento e sua relação com grileiros de terras.

No primeiro pronunciamento de Jair Bolsonaro para a Assembleia Geral das Nações Unidas, a agenda de política externa construída foi defendida e aprofundada (BERMÚDEZ, 2019). O presidente utilizou seu discurso para atacar o socialismo ao vinculá-lo ao governo do PT, criticou Cuba e o Programa Mais Médicos, que considerou uma forma de trabalho escravo, além da onipresente questão venezuelana. Ademais, defendeu a política ambiental 
do país, com fortes críticas à comunidade internacional e sua preocupação com o desmatamento na Amazônia.

Para entender como a PEB vem sendo construída no atual governo é possível apontar a importância de três grupos na sua formulação: o primeiro seria o dos 'olavistas', aqueles mais próximas às 'ideias' propagadas pelo guru de muitos seguidores do presidente - mesmo que com brigas frequentes com Bolsonaro -, Olavo de Carvalho. Figuras como o próprio ministro Ernesto Araújo, os filhos do presidente e Filipe Martins, assessor do presidente para assuntos internacionais compõem tal grupo. A característica mais marcante de tal grupo seria a sua crença na chamada guerra cultural, especialmente na suposta defesa da cultura ocidental em que eles estariam. Uma cruzada cultural travada contra os globalistas, que teriam contaminado países e organismos internacionais. Soma-se ao caldo a defesa de uma posição pró-Washington e um forte anticomunismo, o que fica claro na questão venezuelana.

Um segundo grupo seriam os ditos 'técnicos' da área econômica, a quem podemos chamar de os 'liberais'. Esses buscam alcançar a reorganização econômica brasileira e o reposicionamento do país no cenário internacional. A busca de se fazer as Reformas Econômicas internamente visando à atração de investidores e à maior confiança do mercado mundial demonstram a forte ligação entre a agenda econômica do Ministro Paulo Guedes com a política exterior adotada por Brasília. Aqui, também há a busca por um suposto liberalismo na política econômica e comercial brasileira, o que fica claro com as escolhas de novas parcerias, a retomada de outras e o abandonado de estratégias até então vigentes, a vontade de entrar na OCDE, o abandono da posição do país como um país em desenvolvimento e a reforma do Mercosul - voltando ao seu caráter estritamente comercial, em contraposição à expansão vivida a partir do governo Lula. A preferência pelo bilateralismo em detrimento do multilateralismo é forte nesse segmento, apesar de vangloriar-se da concretização do Acordo Mercosul-UE, o qual está em risco de não se materializar, em especial devido à política ambiental do governo, que tem forte apelo para a questão econômica.

Por último, temos um grupo que não é novo, tampouco sem expressividade no que toca à formulação da política exterior brasileira, os militares. A caserna sempre exerceu forte influência sobre a política nacional, nem ficando a política exterior fora deste quadro. Um governo com tantos generais e outros militares nos seus quadros não ficaria isento dessa influência, mesmo porque o presidente e o vice-presidente, Hamilton Mourão, também são 
oriundos das academias e dos quartéis do exército. O elemento de novidade, nesta nova fase da influência militar sobre a política exterior brasileira, é sua transformação em relação àquela que foi marca dos regimes militares no século passado. A tentativa de venda da Embraer para a Boeing, o acordo com os EUA para que estes utilizem a base de Alcântara com salvaguardas a sua tecnologia e a venda do pré-sal são alguns dos exemplos que chocam em relação ao que os anos de chumbo apresentaram. Tal atuação pouco nacionalista é acentuada pela defesa da parceria preferencial com Washington e pela reconstrução de uma retórica anticomunista em um discurso de 'garantia da ordem', colocando o país em linha de choque com outras nações, inclusive na América do Sul.

Com esse cenário, o que pode ser apontado como um possível eixo central ou ponto de encontro entre os diferentes interesses dos grupos mais fortes na elaboração da política externa brasileira seria seu profundo caráter americanista e pró-ocidente. A defesa de uma aproximação e ligação com os EUA é clara nos três grupos apresentados, bem como um discurso de priorizar parceiros que sejam defensores dos valores ocidentais, fundamentais para a noção de nação e cultura do governo Bolsonaro.

Como apresentado nas seções anteriores, mudanças na política externa sempre ocorreram, mas eram mudanças menos drásticas, de ajustes ou programas, a partir do modelo de Hermann (1990), contudo, a atual composição de elites e grupos no poder do governo Bolsonaro apresenta um momento sem precedentes para o país. A partir dos fatos apresentados, da atuação exterior brasileira e da composição dos grupos mais atuantes na formulação da estratégia internacional brasileira, é possível que estejamos presenciando um momento de mudança de orientação na política externa brasileira, algo que não encontra paralelos em momentos anteriores.

Tomando como eixos principais da política externa brasileira a busca pelo desenvolvimento nacional, a não intervenção em assuntos domésticos, a resolução pacífica de conflitos, a garantia da soberania e autonomia nacional e a busca por um papel de liderança no sistema internacional, o que presenciamos é o abandono de tais eixos. Para perceber essa situação, iremos retomar alguns momentos importantes nesses quase 18 meses do governo Bolsonaro.

Após visita aos EUA, Bolsonaro opta por renunciar ao tratamento especial na OMC, em troca de um possível apoio de Washington ao pleito brasileiro de entrar na OCDE, é uma modificação gravíssima na atuação do Brasil e do seu posicionamento no sistema 
internacional. Essa modificação foi seguida pela opção estadunidense de retirar o Brasil da lista de países em desenvolvimento (TREVIZAN, 2019; BOLSONARO..., 2019b; BENITES, 2019; SALATI, 2020). O efeito material dessa situação e seus impactos no desenvolvimento nacional ainda estão para ser determinados, mas os riscos são altos na medida em que esse tratamento especial garantia ao país benefícios nas trocas comerciais, créditos, prazos etc. Outro importante elemento que precisa ser destacado é a posição brasileira frente à crise climática, o negacionismo do governo na área e as ações que prejudicam o meio ambiente no nível interno afetam as mercadorias brasileiras e a sua negociação em diversos mercados, além de comprometer repasses ao governo como no caso do Fundo da Amazônia (OLIVEIRA, J; ALESSI, G; BEDINELLI, 2019; NEGRÃO, 2019).

No que tange à não interferência em assuntos domésticos, o governo Bolsonaro coleciona uma lista expressiva. Para nos atermos a alguns casos, separamos os casos na América do Sul, que já são suficientes para demonstrar o novo rumo dado à política exterior brasileira. A crise com a Venezuela, já declarada desde antes de eleito, tendo em vista sua postura contrária ao governo de Maduro, foi acentuada pela posição de Bolsonaro de reconhecer Juan Guaidó como presidente do país (BOLSONARO..., 2019C), alinhando-se à postura dos EUA. Ainda em 2019, o governo brasileiro embarca em outro apoio a uma liderança regional, a senadora Jeanine Áñez é reconhecida por Brasília como a presidenta da Bolívia, após o golpe de Estado que derrubou Evo Morales, fato que hoje fica evidente com constatação de que não houve fraude nas eleições que culminaram com a vitória de Evo (FRAZÃO, 2019; LABORDE, 2020). Um outro momento foi registrado durante as eleições para presidente na Argentina, quando Bolsonaro alega que trabalhava para evitar que a oposição ganhasse no país, declarando seu apoio ao então presidente, Mauricio Macri. Não bastasse o apoio durante a eleição, Bolsonaro lamenta, após o pleito, a vitória do opositor Alberto Fernández (BOLSONARO, 2019), que tinha como vice a ex-presidenta Cristina Kirchner.

No que tange à resolução pacífica de conflitos, o governo Bolsonaro, novamente, modifica a agenda nacional e adota um discurso intervencionista e belicoso, tanto domesticamente quanto internacionalmente. Essa posição fica clara nos apoios ao governo de Israel e em sua ação, na maioria das vezes, violenta em relação aos povos Palestinos (GOVERNO..., 2019) e, também, no apoio quase incondicional às ações estadunidense, sob o pretexto de que este estaria defendendo o ocidente (PASSARINHO, 2020). Contudo, o 
momento que mais se destaca é, mais uma vez, na América do Sul. A crise Venezuelana levou o governo Bolsonaro a adotar um discurso de apoio a uma possível intervenção militar estadunidense no país (BOLSANARO, 2019a). Apesar de uma tentativa de abafar tal posicionamento e algumas disputas internas, figuras de grande destaque no governo, inclusive os filhos do presidente, apoiavam tal postura, como ficou evidente no episódio de invasão da embaixada venezuelana em Brasília (PUTTI, 2019).

No que diz respeito à soberania e autonomia nacional, muitos são os elementos possíveis de destacarmos. Contudo, para não nos alongarmos nos exemplos, aqueles que tornam clara essa nova postura do Brasil seriam: o acordo de utilização da base de Alcântara pelos EUA (MAZUI, 2019) e a venda da Embraer para a Boeing - antes mesmo de o acordo não se concretizar, o presidente já afirmava a possibilidade de tentar a venda para outra empresa caso a Boeing cancelasse o acordo (BOLSONARO, 2019b; CARVALHO, 2020). Nesses dois exemplos, o governo Bolsonaro modificou uma postura nacional de proteger setores estratégicos e de interesse público, preferindo uma postura menos autonomista e que colocou a soberania nacional em segundo plano.

Com todos esses elementos, não restam dúvidas sobre a ameaça que o governo Bolsonaro representa aos anseios brasileiros de alcançar uma posição de liderança no sistema internacional. Apesar de o governo adotar uma retórica de que busca colocar o país em uma posição de maior destaque, suas ações levam o Brasil no caminho contrário (QUERO; PASSARINHO, 2019). A política ambiental tanto no nível doméstico quanto internacional é um dos principais destaques dessa depreciação da imagem brasileiro no exterior, mas a atuação do governo frente à pandemia da Covid-19 acrescentou contornos ainda mais drásticos (PASSARINHO, 2019; SÁ, 2020.

A partir dessa realidade é possível compreender os motivos que levaram profissionais da área como Rubens Ricupero, diplomata desde os anos 1960, ter afirmado em entrevista à UOL que a política externa do governo Bolsonaro "se alinha de uma maneira subserviente, como nunca tínhamos visto em 200 anos de história, como um governo absolutamente alucinado" (apud ESSE..., 2020,). Em outra entrevista, Ricupero (apud CHADE, 2019a) afirmou:

É uma política externa de ruptura com o que vinha se fazendo antes, porque, apesar das diferenças que havia, compreensiveis, entre Lula e Fernando Henrique, a política externa brasileira era, no fundo, sempre a busca de autonomia. [...] Agora existe, de fato, uma ruptura, surge claramente um novo paradigma. 
Dessa maneira, o que percebemos até o presente momento é o abandono de tradições e opções feitas na atuação internacional do Brasil. Essa modificação, no entanto, vem sendo feita de maneira mais drástica que nos momentos anteriores, quando ajustes e diferenças nas conduções representavam a regra. Agora, o bloco no poder junto a Bolsonaro e as elites que influenciam na formulação da política exterior conduzem o Brasil a uma atuação que combina escolhas não vistas em momentos anteriores.

\section{Conclusão}

Alterar o entendimento da política externa como política de Estado para uma política pública retira sua singularidade e a condiciona novas características. Esse entendimento contradiz o discurso dominante de que a política externa é desvinculada da política doméstica, dos conflitos e das facções (LIMA, 2005). Ou seja, sua formulação e implementação devem ser entendidas dentro das dinâmicas de governo e não mais como reflexo de interesses nacionais alijados das conjunturas político partidárias (MILANI; PINHEIRO, 2013).

A maior mobilização da política externa nos assuntos eleitorais reflete o interesse da sociedade pelo tema e a necessidade de pensar sua formulação a partir de uma perspectiva mais ampla do que apenas o corpo burocrático de Estado ou os membros do Executivo Federal. A construção de uma política externa sem transparência pode ocasionar enormes danos e perdas para a sociedade em geral, além de refletir apenas os interesses de uma parcela específica da sociedade não necessariamente representativa.

Ademais, o enfraquecimento da dimensão da agenda comercial dentro do MRE, ministério eminentemente político, para o Ministério da Indústria, Comércio Exterior e Serviços (MDIC) ou agências reguladoras de comércio é uma recorrente na pauta dos grandes industriais brasileiros que lentamente se materializa. Milani e Pinheiro (2017) argumentam que essa medida torna a política comercial mais suscetível à influência de interesses corporativos e lobbies de grandes corporações, opondo-se ao movimento de democratização do processo decisório. Esse contexto promove um acolhimento automático do governo das pautas apresentadas pelos setores do empresariado, excluindo a participação dos movimentos sociais, sindicais e populares. 
Agrava-se, então, o déficit democrático, o qual se transforma em uma muralha de defesa dos governos para a condução de uma agenda internacional alinhada exclusivamente a seus interesses e das organizações que compuserem o bloco no poder. O pensamento único na condução da política externa, além de antidemocrático, permite que, em momento de exceção como no governo Jair Bolsonaro, a condução ideológica da PEB cause inúmeras instabilidades políticas para a relação do país com a comunidade internacional e a desestruturação da América Latina.

Ainda que estejamos caminhando para a metade do governo Bolsonaro, este já coleciona momentos e importantes fatos no que toca sua política externa. Ao traçarmos os principais momentos e a agenda do governo Bolsonaro, é possível apontar para uma importante inflexão na atuação exterior brasileira. Apesar de as mudanças e correções não serem algo novo ou incomum, chama a atenção a magnitude das transformações levadas a cabo pelo atual governo brasileiro.

Antes, imaginava-se que as estruturas do Estado seriam capazes de evitar que mudanças bruscas ocorressem em agendas que se julgava ser 'política de Estado'. O insulamento perdurou no vocabulário do Itamaraty e de acadêmicos, dificultando a produção de conhecimento que focasse nas mudanças na política exterior brasileira e a sua ligação com as ideologias dos governos. Além disso, entender a política externa como uma política pública passa a ser fundamental e inegável, especialmente após as mudanças drásticas no governo Bolsonaro e a sua ligação com as demais agendas domésticas e posturas retóricas, discursivas e ideológicas do governo.

Construir mecanismos de controle social, de prestação de contas e espaços institucionais de formulação política permitiriam ao Brasil, nesse momento, frear os ímpetos do governo Bolsonaro sobre as estruturas de Estado. O uso iminentemente político dos órgãos do MRE, em especial da Fundação Alexandre de Gusmão (FUNAG), expõe fragilidades no modelo de organização ministerial e seu profundo déficit democrático. As movimentações do Itamaraty sob chancela de Ernesto Araújo promovem graves prejuízos à reputação externa do país e ao relacionamento com parceiros estratégicos?

\footnotetext{
7 Entre maio e junho de 2020, em uma série de seminários promovidos pela FUNAG, palestrantes convidados para palestrarem sobre o mundo pós-pandemia do COVID-19 proferiram declarações contra o Estado chinês e sua suposta responsabilidade sobre a pandemia.
} 
Das discussões feitas neste artigo, nota-se que a política externa nasceu sendo uma política pública como as outras, imbuída de barganhas políticas e associada às dinâmicas de política interna (CHEIBUB, 1985). O discurso reproduzido classificando-a como uma política insulada e separada dos conflitos internos não se verifica na realidade (PINHEIRO; MILANI, 2013). A dinâmica de barganha e a priorização de interesses particulares ao interesse público ainda ocorre.

A gestão Bolsonaro promoveu diversos exemplos de que as disputas e os interesses de política interna interferem na política externa. Pode-se citar a reiterada intenção de indicar o filho do presidente - sem experiência na área diplomática - para chefe da missão diplomática nos EUA, uma das embaixadas mais importantes para o Brasil; discursos de cunho ideológico do presidente defendendo a transferência da embaixada de Tel Aviv para a área disputada de Jerusalém, prejudicando relações com os países árabes (grandes parceiros comerciais do Brasil); discursos de membros do governo que refletem interesses pessoais e ideológicos prejudicando relações com a China e a Argentina, dois dos maiores parceiros comerciais do país.

Por fim, cabe ressaltar que a defesa da democracia, não apenas como cumprimento dos ritos administrativos e burocráticos, mas como um amplo processo de validação e participação da sociedade civil nas ações tomadas pelos governos é necessária para transparência e legitimação da política externa. Além disso, garante que a constante disputa por hegemonia das forças sociais atuantes no país permaneça no campo programático e possibilite o amadurecimento das instituições de Estado. Consequentemente, possibilita a materialização da política externa como uma política pública com garantia do debate político amplo e efetivo de todos os segmentos da sociedade.

\section{Referências}

AÉCIO Neves promete alinhar política externa à agenda comercial e retomar negociações de acordos bilaterais. Portal da Indústria, Brasília, DF, 30 jul. 2014. Disponível em: https://noticias.portaldaindustria.com.br/noticias/competitividade/aecio-neves-prometealinhar-politica-externa-a-agenda-comercial-e-retomar-negociacoes-de-acordosbilaterais/. Acesso em: 05 jun. 2020. 
AMADO, R. A Política Externa no governo João Goulart. In: ALBUQUERQUE, J. A. G. (org.). Sessenta Anos de Política Externa Brasileira, 1930-1990. São Paulo: Núcleo de Pesquisa em Relações Internacionais da USP/Cultura Editores Associados, 1996. v. 1.

BAPTISTA, J. V. M. A Central Única dos Trabalhadores (CUT) e o Mercosul: conflitos e contradições da participação social nos governos Lula da Silva e Dilma Rousseff (20032014). 2020. Dissertação (Mestrado em Relações Internacionais) - UNESP/UNICAMP/PUC, São Paulo, 2020. Disponível em:

https://repositorio.unesp.br/bitstream/handle/11449/192119/

baptista_jvm_me_mar.pdf?sequence=3\&isAllowed=y. Acesso em: 14 dez. 2020.

BELLIX, L.; GUIMARAES, C. B.; MACHADO, J. Qual o conceito de governo aberto? uma aproximação aos seus princípios. In: CONGRESO INTERNACIONAL EN GOBIERNO, ADMINISTRACIÓN Y POLITICAS PÚBLICAS, 7., 2016. Madrid. Anais [...] Madrid: GIGAPP, 2016. Disponível em: https://ceweb.br/media/docs/publicacoes/19/Qual\%20 conceito\%20de\%20Governo\%20Aberto-atualizado_03-out2016.pdf. Acesso em: $14 \mathrm{dez}$. 2020.

BENITES, Afonso. "Brasil deixou seu status na OMC para se agarrar a uma sinalização na OCDE. Não é prudente". El País, Brasília, 12 out. 2019. Diplomacia. Disponível em: https://brasil.elpais.com/brasil/2019/10/11/politica/1570827156_314753.html. Acesso em: 18 jun. 2020.

BOLSONARO afirma que transferirá embaixada para Jerusalém até 2021. Folha de São Paulo, 03 fev. 2020. Mundo. Disponível em: https://www1.folha.uol.com.br/mundo/2020 102/bolsonaro-afirma-que-transferira-embaixada-para-jerusalem-ate-2021.shtml. Acesso em: 19 jun. 2020.

BOLSONARO aprova venda da Embraer à estadunidense Boeing. Brasil de Fato, São Paulo, 11 jan. 2019. Disponível em: https://www.brasildefato.com.br/2019/01/11/bolsonaro-aprovavenda-da-embraer-a-estadunidense-boeing. Acesso em: 18 jun. 2020. b.

BOLSONARO atende Trump e vai 'abrir mão' de tratamento especial do Brasil na OMC, diz Itamaraty. G1, Brasília, 19 mar. 2019. Política. Disponível em: https://g1.globo.com/politica /noticia/2019/03/19/bolsonaro-atende-trump-e-vai-comecar-a-abrir-mao-de-tratamentoespecial-do-brasil-na-omc-diz-itamaraty.ghtml. Acesso em: 18 jun. 2020. b.

BOLSONARO diz que trabalha para impedir vitória da oposição na Argentina. Veja, 10 out. 2019. Mundo. Disponível em: https://veja.abril.com.br/mundo/bolsonaro-diz-que-trabalhapara-impedir-vitoria-da-oposicao-na-argentina/. Acesso em: 18 jun. 2020. d.

BOLSONARO: Falarei com Congresso em caso de invasão na Venezuela pelos EUA. Exame, Brasília, o9 abr. 2019. Brasil. Disponível em: https://exame.com/brasil/bolsonaro-falareicom-congresso-em-caso-de-invasao-na-venezuela-pelos-eva/. Acesso em: 18 jun. 2020. a.

BOLSONARO lamenta vitória de Fernández e diz que não vai cumprimentá-lo. UOL, São Paulo, 28 out. 2019. Internacional. Disponível em: 
https://noticias.uol.com.br/internacional/ultimas-noticias/2019/10/28/bolsonaro-lamentavitoria-de-fernandez-e-diz-que-nao-vai-cumprimenta-lo.htm. Acesso em: 18 jun. 2020.

BOLSONARO não participa da conferência climática da ONU. Diário de Pernambuco, 02 dez. 2019. Disponível em: https://www.diariodepernambuco.com.br/noticia/politica/2019 /12/bolsonaro-nao-participa-da-conferencia-climatica-da-onu.html. Acesso em 05 jun. 2020. a.

BOLSONARO reconhece Juan Guaidó como presidente da Venezuela. G1, 23 jan. 2019. Política. Disponível em: https://g1.globo.com/politica/noticia/2019/01/23/brasil-diz-quereconhece-juan-guaido-como-presidente-da-venezuela.ghtml. Acesso em: 18 jun. 2020. c.

CARVALHO, Daniel. Bolsonaro diz que se Boeing desfizer acordo, Embraer poderá negociar com outra empresa. Folha de São Paulo, Brasília, 27 abr. 2020. Mercado. Disponível em: https://www1.folha.vol.com.br/mercado/2020/04/bolsonaro-diz-que-se-boeing-desfizeracordo-embraer-podera-negociar-com-outra-empresa.shtml. Acesso em: 18 jun. 2020.

CASARÕES, Guilherme. O papel do Itamaraty na definição da política externa do governo Collor de Mello. Revista Brasileira de Política Internacional, Brasília, DF, v. 55, n. 1, p. 135153, 2012. Disponível em: https://www.scielo.br/pdf/rbpi/v55n1/ao8v55n1.pdf. Acesso em: 14 dez. 2020.

CERIONI, C. Na ONU, Damares endossa posição contra aborto e pede paz para Venezuela. Exame, São Paulo, 25 fev. 2019. Disponível em: https://exame.com/brasil/na-onu-damaresendossa-posicao-contra-aborto-e-pede-paz-na-venezuela/. Acesso em 05 jun. 2020.

CERVO, Amado; BUENO, Clodoaldo. História da Política Exterior do Brasil. Brasília, DF: Editora UNB, 2002.

CHADE, Jamil. A ambígua relação do governo Bolsonaro com o multilateralismo. UOL, São Paulo, 11 mar. 2019. Disponível em: https://jamilchade.blogosfera.uol.com.br/2019/03/11/aambigua-relacao-do-governo-bolsonaro-com-o-multilateralismo/. Acesso em: 19 jun. 2020.

CHADE, Jamil. 100 dias que mudaram a posição do Brasil no mundo. UOL, Genebra, 10 abr. 2019. Disponível em: https://jamilchade.blogosfera.uol.com.br/2019/04/10/100-dias-quemudaram-a-posicao-do-brasil-no-mundo/. Acesso em: 19 jun. 2020. a.

CHEIBUB, Zairo B.. Diplomacia e construção institucional: o Itamaraty em perspectiva histórica. Dados, Rio de Janeiro, v. 28, n. 1, 1985.

CRUZ-RUBIO, C. N. O que é (e o que não é) Governo Aberto? uma discussão conceitual. Revista Temas de Administração Pública, Araraquara, v. 10, n. 1, p. 129-148, 2015.

"ESSE governo tem percepção de um universo de ficção", diz Ricupero. UOL, São Paulo, 28 abr. 2020. Política. Disponível em: https://noticias.uol.com.br/politica/ultimasnoticias/2020/04/28/esse-governo-tem-percepcao-de-um-universo-de-ficcao-dizricupero.htm. Acesso em: 19 jun. 2020. 
FARIA, Carlos A. P. de. O Itamaraty e a Política Externa Brasileira: Do Insulamento à Busca de Coordenação dos Atores Governamentais e de Cooperação com os Agentes Societários. Contexto Internacional, Rio de Janeiro, v. 34, n. 1, jan./jun. 2012. Disponível em: https://www.scielo.br/pdf/cint/v34n1/v34n1aog.pdf. Acesso em: 14 dez. 2020.

FARIA, C. F. Estado e organizações da sociedade civil no Brasil contemporâneo: construindo uma sinergia positiva? Revista Sociologia e Política, Curitiba, v. 18, n. 36, p. 187-204, 2010. Disponível em: https://revistas.ufpr.br/rsp/article/view/31638/20168. Acesso em: 14 dez. 2020.

FICO, Carlos. O grande irmão. Rio de Janeiro: Civilização Brasileira, 2008.

FRAZÃO, Felipe. Governo Bolsonaro reconhece Jeanine Áñez como presidenta interina da Bolívia. O Estado de São Paulo, Brasília, DF, 13 nov. 2019. Internacional. Disponível em: https://internacional.estadao.com.br/noticias/geral,no-twitter-itamaraty-reconhecejeanine-anez-como-presidente-interina-da-bolivia,70003087602. Acesso em: 18 jun. 2020.

GOVERNO Bolsonaro muda tradição e vota na ONU contra condenação a Israel por repressão a Palestinos. O Globo, Rio de Janeiro, 22 mar. 2019. Mundo. Disponível em: https://oglobo.globo.com/mundo/governo-bolsonaro-muda-tradicao-vota-na-onu-contracondenacao-israel-por-repressao-palestinos-23543123. Acesso em 18 jun. 2020.

LABORDE, Antonia. Estudo do MIT não encontra evidência estatística de fraude nas eleições da Bolívia. El País, Washington, 28 fev. 2020. Internacional. Disponível em: https://brasil.elpais.com/internacional/2020-02-28/estudo-do-mit-nao-encontra-evidenciaestatistica-de-fraude-nas-eleicoes-da-bolivia.html. Acesso em: 18 jun. 2020.

LIMA, M. R. S. Aspiração internacional e política externa. Revista Brasileira de Comércio Exterior, n. 82, a. XIX, p. 4-19, jan./mar. 2005.

LIMA, Maria Regina Soares de. Relações interamericanas: a nova agenda sul-americana e o Brasil. Lua Nova, São Paulo, n. 90, p. 167-201, dez. 2013.

LOPES, Dawisson Belém; FARIA, Carlos Aurélio Pimenta. Eleições presidenciais e política externa brasileira. Estudos Internacionais, v. 2, n. 2, p. 139-148, jul./dez. 2014.

MARIANO, K. L. P. A participação das Centrais Sindicais no Mercosul (1991-2001). São Paulo: Cultura Acadêmica, 2011.

MARIANO, K. L. P. Parlamento do Mercosul, integração e déficit democrático. Século XXI, Porto Alegre, v. 4, n. 2, jul./dez. 2013.

MAZUI, Guilherme. Brasil assina acordo que permite aos EUA lançar satélites da base de Alcântara. G1, Brasília, DF, 18 mar. 2019. Política. Disponível em: https://g1.globo.com/ politica/noticia/2019/03/18/brasil-assina-acordo-que-permite-aos-eua-lancar-satelites-dabase-de-alcantara.ghtml. Acesso em: 18 jun. 2020. 
MEDEIROS, Klei P.; VILLAS-BOAS, Vinícios; ANDRADE, Enrico. Política externa conservadora: uma nova matriz no Brasil? Le Monde Diplomatique Brasil, São Paulo, 21 mar. 2019. Disponível em: https://diplomatique.org.br/79475-2/. Acesso em: 19 jun. 2020.

MELLO, Flavia de Campos. Política externa brasileira e os blocos internacionais. São Paulo Perspectiva, São Paulo, v. 16, n. 1, p. 37-43, jan. 2002. Disponível em: https://www.scielo.br /scielo.php?script=sci_arttext\&pid=S0102-88392002000100005 . Acesso em: 14 dez. 2020.

MILANI, C. R. S; PINHEIRO, L. Política externa brasileira: os desafios de sua caracterização como política pública. Contexto Internacional, Rio de Janeiro, v. 35, n. 1, jan./jun. 2013. Disponível em: https://www.scielo.br/pdf/cint/v35n1/a01v35n1.pdf. Acesso em: 14 dez. 2020.

MILANI, C. R. S; PINHEIRO, L. The Politics of Brazilian Foreign Policy and Its Analytical Challenges. Foreign Policy Analysis, London, v. 13, 2017. Disponível em:

https://carlosmilani.files. wordpress.com/2012/12/milani_pinheiro_fpa_2017.pdf. Acesso em: 14 dez. 2020.

MINISTRO do Meio Ambiente defende passar a "boiada" e "mudar" regras enquanto a atenção da mídia está voltada para a Covid-19. G1, 22 mai. 2020. Política. Disponível em: https://g1.globo.com/politica/noticia/2020/05/22/ministro-do-meio-ambiente-defendepassar-a-boiada-e-mudar-regramento-e-simplificar-normas.ghtml. Acesso em: 19 jun. 2020.

MORAVCSIK, Andrew. Taking preferences seriously: a liberal theory of international politics. International Organization 51, [S. L.], n. 4, p. 513-553, autumn 1997. Disponível em: http://www.princeton.edu/ amoravcs/library/preferences.pdf. Acesso em: 14 dez. 2020.

MOURA, Gerson. Autonomia na Dependência. Rio de Janeiro: Ática, 1984.

NEGRÃO, Heloísa. Após Alemanha, Noruega também bloqueia repasses para Amazônia. El País, São Paulo, 16 ago. 2019. Brasil. Disponível em: https://brasil.elpais.com/brasil/ 2019/08/15/politica/1565898219_277747.html. Acesso em: 18 jun. 2020.

OLIVEIRA, J. A. Legislativo e política externa: das (in)conveniências da abdicação. Working Papers Caeni, São Paulo, n. 3, 2003.

OLIVEIRA, J.; ALESSI, G.; BEDINELLI, T. Política ambiental de Bolsonaro ameaça acordo com a UE e alarma até agronegócio exportador. El País, São Paulo, 17 ago. 2019. Meio Ambiente. Disponível em: https://brasil.elpais.com/brasil/2019/08/16/politica/15659 09766_177145.html. Acesso em: 18 jun. 2020.

A OPÇÃO Sul-Americana de Marco Aurélio Garcia. Outras Palavras, São Paulo, 21 jul. 2017. Disponível em: https://outraspalavras.net/sem-categoria/a-opcao-sul-americana-de-marcoaurelio-garcia/. Acesso em: 14 dez. 2020. 
PARTIDO DOS TRABALHADORES. Bases do Programa de Governo, 1994. [S. L.: S. n.], 1994. Disponível em: https://fpabramo.org.br/csbh/wp-content/uploads/sites/3/2017/04/02basesdoprogramadegov.pdf. Acesso em: 14 dez. 2020.

PARTIDO DOS TRABALHADORES. União do Povo Muda Brasil, 1998. [S. L.: S. n.], 1998. Disponível em: https://lae.princeton.edu/catalog/22b15564-d146-4e70-974bdfd 47c10d959? locale $=$ pt $-B R \# ? c=0 \& m=0 \& s=0 \& c v=0 \& x y w h=-827 \% 2 C-$ 172\%2 $3783 \% 2 C_{3420}$. Acesso em: 14 dez. 2020.

PASSARINHO, Nathalia. Como a política ambiental de Bolsonaro afetou imagem do Brasil em 2019 e quais as consequências disso. UOL, Londres, 31 dez. 2019. Meio Ambiente. Disponível em: https://noticias.uol.com.br/meio-ambiente/ultimasnoticias/bbc/2019/12/31/como-politica-ambiental-de-bolsonaro-afetou-a-imagem-dobrasil-em-2019-e-quais-as-consequencias-disso.htm. Acesso em: 18 jun. 2020.

PASSARINHO, Nathalia. EUA x Irã: o que o Brasil tem a ganhar ou perder ao apoiar Trump no conflito. BBC Brasil, São Paulo, 07 jan. 2020. Brasil. Disponível em:

https://www.bbc.com/portuguese/internacional-51026485. Acesso em: 18 jan. 2020.

PECEQUILO, Cristina Soreanu. Teoria das relações internacionais: O mapa do caminho: teoria e prática. Rio de Janeiro: Alta Books, 2016.

PINHEIRO, Letícia; MILANI, Carlos R. S. Política externa brasileira: os desafios de sua caracterização como política pública. Contexto Internacional, Rio de Janeiro, v. 35, n. 1, p. 11-41, jan./jun. 2013. Disponível em: https://www.scielo.br/pdf/cint/v35n1/a01v35n1.pdf. Acesso em: 14 dez. 2020.

PUTNAM, Robert. Diplomacy and domestic politics: the logic of two-level games. International Organization, [S. L.], v. 42, n. 3, p. 427-460, 1988. Disponível em: https://www.jstor.org/stable/pdf/2706785.pdf?refreqid=excelsior\%3A86aoaf136oofb 5 e478c a8b9521d12073. Acesso em: 14 dez. 2020.

PUTTI, Alexandre. Eduardo Bolsonaro apoia invasão da embaixada da Venezuela em Brasília. Carta Capital, São Paulo, 13 nov. 2019. Política. Disponível em: https://www.cartacapital.com.br/politica/eduardo-bolsonaro-apoia-invasao-da-embaixadada-venezuela-em-brasilia/. Acesso em: 18 jun. 2020.

QUERO, Caio. Para 'evitar promoção do aborto', Brasil critica menção à saúde reprodutiva da mulher em documento da ONU. BBC News Brasil, São Paulo, 26 mar. 2019. Disponível em https://www.bbc.com/portuguese/brasil-47675399. Acesso em 05 jun. 2020.

QUERO, Caio; PASSARINHO, Nathalia. Governo Bolsonaro ameaça prestígio internacional do país, dizem diplomatas brasileiros. BBC News Brasil, São Paulo, 31 mai. 2019. Brasil.

Disponível em: https://www.bbc.com/portuguese/brasil-48402241. Acesso em: 18 jun. 2020.

RICUPERO, Rubens. O Brasil no mundo. In: SCHWARCZ, Lilia (org.). História do Brasil nação: 1808-2010. Rio de Janeiro: Objetiva, 2011. v. 1. 
RICUPERO, Rubens. A diplomacia na construção do Brasil (1750-2016). Rio de Janeiro: Ed. Versal, 2017.

ROSENAU, James (org.). Domestic sources of foreign policy. Londres: Collier-Macmillan Limited, 1967.

SÁ, Nelson de. Imagem de Bolsonaro derrete no exterior, e mundo teme Brasil. Folha de São Paulo, São Paulo, 30 mai. 2020. Mundo. Disponível em: https://www1.folha.vol.com. br/mundo/2020/05/imagem-de-bolsonaro-derrete-no-exterior-e-mundo-teme-brasil.shtml. Acesso em: 18 jun. 2020.

SALATI, Paula. EUA retiram Brasil da lista de países em desenvolvimento; medida pode restringir benefícios comerciais. G1, Rio de Janeiro, 10 fev. 2020. Economia. Disponível em: https://g1.globo.com/economia/noticia/2020/02/10/eua-tiram-brasil-da-lista-de-paises-emdesenvolvimento-pais-pode-perder-tratamento-preferencial-em-negociacoes.ghtml. Acesso em: 18 jun. 2020.

SNYDER, R. C.; BRUCK, H. W.; SAPIN, B. (org.). Foreign policy decision making: an approach to the study of international politics. Nova lorque: Free Press, 1962.

TREVIZAN, Karina. Encontro de Bolsonaro e Trump acende debate sobre tratamento especial na OMC; entenda. G1, Rio de Janeiro, 19 mar. 2019. Economia. Disponível em: https://g1.globo.com/economia/noticia/2019/03/19/encontro-de-bolsonaro-e-trumpacende-debate-sobre-tratamento-especial-do-brasil-na-omc-entenda.ghtml. Acesso em 18 jun. 2020.

ULHÔA, R. Serra ataca e diz que país pode virar Venezuela se Lula vencer. Folha de São Paulo, São Paulo, 11 out. 2002. Disponível em: https://www1.folha.uol.com.br/folha/brasil /ultg6u40275 .shtml. Acesso em 02 jun. 2020.

VALLADÃO, Alfredo. Política externa de governo Bolsonaro deve priorizar relações com países ricos. RFI, [S. L.], 05 nov. 2018. Disponível em: http://www.rfi.fr/br/brasil/20181105-0mundo-agora. Acesso em: 19 jun. 2020.

VENTURA, D. As assimetrias entre o Mercosul e a União Europeia: os desafios de uma associação inter-regional. Barueri: Manole, 2003.

VERDÉLIO, A. Brasil formaliza saída da Unasul para integrar Prosul. Agência Brasil, Brasília, DF, 16 abr. 2019. Disponível em: https://agenciabrasil.ebc.com.br/internacional/ noticia/2019-04/brasil-formaliza-saida-da-unasul-para-integrar-prosul.Acesso em o5 jun. 2020. 


\section{Detalhes dos autores}

\section{Artur Cruz Bertolucci}

Mestre pelo Programa de Pós-Graduação em Relações Internacionais San Tiago Dantas (UNESP/UNICAMP/PUC-SP) e bacharel em Relações Internacionais pela Universidade Federal de Uberlândia (UFU). E-mail: arturbertolucci83@gmail.com ORCID iD: http://orcid.org/0000-0001-56g6-531X

\section{Ana Victória Klovrza Diogo}

Mestranda do Programa de Pós-Graduação em Relações Internacionais da Universidade Federal de Uberlândia (PPGRI - UFU). Bacharel em Relações Internacionais pela Universidade Federal de Uberlândia (2018). Email:anavictoriako4@gmail.com 